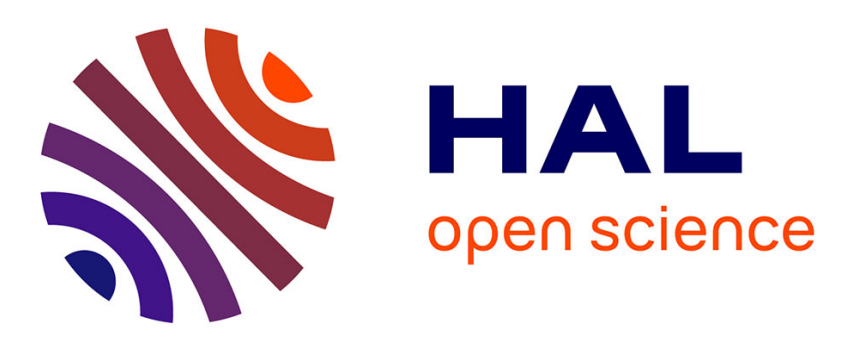

\title{
Determination of the volatile fraction of phosphorus flame retardants in cushioning foam of upholstered furniture: towards respiratory exposure assessment
}

Mylène Ghislain, J. Beigbeder, L. Dumazert, José-Marie Lopez-Cuesta, M. Lounis, S. Leconte, V. Desauziers

\section{To cite this version:}

Mylène Ghislain, J. Beigbeder, L. Dumazert, José-Marie Lopez-Cuesta, M. Lounis, et al.. Determination of the volatile fraction of phosphorus flame retardants in cushioning foam of upholstered furniture: towards respiratory exposure assessment. Environmental Monitoring and Assessment, 2016, 188 (10), 10.1007/s10661-016-5566-y . hal-01709117

\section{HAL Id: hal-01709117 \\ https://hal.science/hal-01709117}

Submitted on 25 May 2021

HAL is a multi-disciplinary open access archive for the deposit and dissemination of scientific research documents, whether they are published or not. The documents may come from teaching and research institutions in France or abroad, or from public or private research centers.
L'archive ouverte pluridisciplinaire HAL, est destinée au dépôt et à la diffusion de documents scientifiques de niveau recherche, publiés ou non, émanant des établissements d'enseignement et de recherche français ou étrangers, des laboratoires publics ou privés. 


\section{Determination of the volatile fraction of phosphorus flame retardants in cushioning foam of upholstered furniture: towards respiratory exposure assessment}

\author{
Mylène Ghislain • Joana Beigbeder • Loïc Dumazert • \\ José-Marie Lopez-Cuesta • Mohammed Lounis • \\ Stéphane Leconte • Valérie Desauziers
}

applied to other types of materials and can be used to rate them according to their potential releases of phosphorus flame retardants.

Keywords Flame retardants · Upholstered furniture · Polyurethane foam $\cdot$ Inhalation exposure assessment

\section{Introduction}

In France, a fire breaks out every 2 min, causing about 800 deaths per year (French Minister of Housing and Sustainable Habitat 2015). Although upholstered furniture is rarely the cause of a fire start, they are dominant in the spread of fire. Therefore, to provide fire protection and to increase the time available for escape, flame retardants can be added to this kind of products to suppress or limit the combustion process.

Upholstered furniture generally has multi-material structure composed of a cushioning foam, an insulating interliner and a coating material (fabric, leather or poly(vinyl chloride) (PVC)). The cushioning material, usually polyurethane foam, is the main fuel of upholstered furniture, so it is often fire-retarded to be less flammable. Ninety-two percent of fireproofed upholstered furniture contains flame retardants (FRs) in the padding. The coating material can also be fire-retarded to act as a barrier and avoid the flame propagation in the cushioning foam. However, $62 \%$ of upholstered furniture still pass the European standardized cigarette ignition test without flame retardants (Chivas et al. 2007; NF EN 1021-1 2014). 
According to the European Flame Retardants Association (EFRA), foams for mattresses and upholstered furniture are generally fireproofed with chlorinated phosphate esters used in combination with nitrogenbased compounds such as melamin salts (European Flame Retardants Association 2015). Brominated flame retardants (BFRs) such as hexabromocyclododecane (HBCD) or polybrominated diphenyl ethers (PBDEs) have also long been used (Covaci et al. 2006). However, the production and use of phosphorus flame retardants (PFRs) in furniture foam have increased due to the worldwide restrictions on some of BFRs, especially PBDEs (Ali et al. 2012; Stapleton et al. 2009; Van der Veen and de Boer 2012). Tributyl phosphate (TBP), triphenyl phosphate (TPP), or tris(2-chloroethyl)-phosphate (TCEP), for example, have been considered as suitable alternatives for BFRs (Van der Veen and de Boer 2012). The main phosphoric esters used are tris-(monochloropropyl)-phosphate (TMCP or TCPP), tris-(dichloropropyl)-phosphate (TDCPP), and tetrakis(2-chlorethyl)dichloroisopentyldiphosphate (BTMCP or V6) (NF EN 1021-1 2014; Van der Veen and de Boer 2012). Due to the presence of both chlorine and phosphorus, these flame retardants can act both in solid and gaseous phases. Stapleton et al. analyzed samples of upholstery and bedding foams purchased between 2003 and 2009. The results confirm the important use of TCPP and TDCPP as flame retardants in upholstered furniture foams (Stapleton et al. 2009).

To date, there is still little information available about the toxicity of PFRs. However, some studies exhibit the toxicity of various organophosphate acid triesters which show strong hemolytic toxicity (Sato et al. 1997). Moreover, some data suggest that phosphoric esters such as TCPP, TDCPP, and TCEP may affect neurodevelopment (Dishaw et al. 2011). TPP is suspected of causing contact dermatitis and proves to be a potent human blood monocyte carboxylesterase inhibitor (Saboori et al. 1991; World Health Organization 1991). TCP and especially the isomer ortho (ToCP) is neurotoxic for humans (World Health Organization 1990). It was also established that TCEP was carcinogenic and teratogenic according to studies carried out on mice and rats (Beth-Hubner and Devilliers 1999; World Health Organization 1998). It was also demonstrated that it can cause damage to the hippocampus of these animals (Tilson et al. 1990). Consequently, this product has been substituted by the TCPP. More recently, the European Chemicals Agency (ECHA) has registered TPP on the Community Rolling Action
Plan (CoRAP) list as substance to be studied because of its suspected endocrine disruptor effect (ANSES 2015; European Chemicals Agency 2016). A study will soon be also led on the carcinogenic and reprotoxic effects of the TCPP and on the neurotoxic effects of the TCP (European Chemicals Agency 2016). The Regulation (EC) No 1772/2008 of the European Parliament and of the Council of 16 December 2008 on classification, labelling and packaging of substances and mixtures classifies TCEP and TDCPP as substances suspected of causing cancer (Carc. 2) (Official journal of the European Union 2008).

Flame retardants can be classified as reactive or additive according to their mode of incorporation into the polymer. Reactive FRs are chemically bound to the polymer, whereas additives are just added during the polymerization process (Marklund et al. 2003; Staaf and Ostman 2005a; Van der Veen and de Boer 2012). This latter is the main incorporation mode for PFRs. Consequently, in this case, flame retardants can migrate into the polymer material and according to their physicochemical properties may be emitted to the air (Staaf and Ostman 2005a). Various studies show that a wide range of phosphoric esters can be found in different compartments of the indoor environment and that upholstered furniture can be one of the sources. Because of their properties, the compounds emitted by the materials are divided between the gas phase, suspended particles, settled dust, and deposits on the surfaces (including human skin) (Little et al. 2012; Salthammer and Bahadir 2009; Weschler and Nazaroff 2008, 2010). Thus, phosphorus flame retardants can be found in indoor air (Carlsson et al. 1997; Hartmann et al. 2004; Marklund et al. 2005; Staaf and Ostman 2005a; Takigami et al., 2009a; Van der Veen and de Boer 2012) or in dust (Marklund et al. 2003; Takigami et al., 2009b; Van der Veen and de Boer 2012), leading to numerous exposure pathways: inhalation, ingestion, especially for young children with hands - mouth contact and skin contact. Therefore, a better understanding of the PFRs partition between air, particles, and surfaces is challenging and requires the determination of PFRs source term, i.e., the volatile fraction of PFRs in material. This latter data is poorly known as main studies focus on air analysis (Aragón et al. 2013; Björklund et al. 2004; Carlsson et al. 1997; Hartmann et al. 2004; Isetun et al., 2004a; Staaf and Ostman 2005b). In other studies, flame retardants are quantitatively recovered from materials, often by solvent extraction (Altwaiq 
et al. 2003; Wang et al. 2015). The obtained results reflect the total amount of flame retardants into the material but do not allow differentiating additive and reactive materials. That means that this method does not allow distinguishing the volatile fraction of FRs which can be emitted to indoor air. Thus, it does not inform about the potential exposure to these compounds. In the literature, few methods describe the analysis of phosphorus flame retardants emissions by materials. Kemmlein et al. studied FRs emissions from consumer products and building materials with various emission test chambers and cells (Kemmlein et al. 2003). Results showed phosphorus flame retardants emissions but also highlighted analytical problems due to compounds' deposit on the sampler walls at ambient temperature $\left(23^{\circ} \mathrm{C}\right)$. That is why the ISO $16000-25$ standard relative to the determination of the emission of semi-volatile organic compounds (including PFRs) by building products in micro-chamber includes a high temperature $\left(220{ }^{\circ} \mathrm{C}\right)$ desorption phase for a total recovery of the emitted compounds (ISO 16000-25 2011). But there is no example of application of the micro-chamber method for the analysis of PFRs emissions in the literature that validates the methodology.

Since recovery methods by solvent extraction do not reflect transfer into gas phase and classical emission tests, chambers are complex to perform and not yet optimized for the analysis of phosphorus flame retardant emissions; another approach is proposed here to characterize the PFRs sources. This study aimed in the development of a HS-SPME method for the assessment of the ability of fire-proof polyurethane foams to release PFRs into gas phase by determining the volatile fraction of PFRs present in materials. HS-SPME is rather commonly applied for the analysis of VOCs emitted by solid samples including materials (Félix et al. 2013; Gröning and Hakkarainen 2001; Kotowska et al. 2012; Kwon et al. 2007; Lattuati-Derieux et al. 2006). However, on our knowledge, it has not yet been applied to flame retardants. HS-SPME presents certain advantages: it is quite easy to implement, allows time-saving, and sampling reproducibility due to automatization and temperature control.

As upholstered furniture is one of the main sources of indoor PFRs, the study focused on polyurethane foams. Seven phosphorus flame retardants were studied (Table 1). The selection is based on the bibliographical data of flame retardants used in the upholstered furniture, their health impact and their physicochemical properties to select the substances the most susceptible to be found in air. The analytical method was developed on laboratory made foams containing known and controlled amounts of the compounds of interest. Phosphorus flame retardants being generally used as additives, they were incorporated directly in the reactant mixture during foam polymerization. A quantification method by standard addition was developed to determine the volatile fraction of flame retardants. After optimization on model materials, the method was applied on commercial polyurethane foams to determine and compare their emission potential.

\section{Materials and methods}

\section{Samples}

Soft polyurethane foams were polymerized by mixing a polyol mixture containing phosphorus flame retardants to isocyanate. The mixture was stirred with a Stirrer LH from Velp Scientifica (Usmate, Italy) for $20 \mathrm{~s}$ at $650 \mathrm{rpm}$ to ensure a homogeneous mix and then poured into an open mold. Free rise foaming was completed after 20$30 \mathrm{~min}$ and foams were removed from the mold. Polyurethane foam panels of $41 \times 24 \mathrm{~cm}$ with a thickness of $1 \mathrm{~cm}$ were obtained. Their densities were 160 or $200 \mathrm{~kg} \mathrm{~m}^{-3}$, depending on the amounts of flame retardants added to the mixture (Table 2). Six foams have been implemented for the model materials: blank polyurethane foam (without flame retardant), two containing all the compounds of interest with individual concentrations of respectively 5 and $7.6 \mathrm{wt} \%$ and three each containing one compound, respectively TCPP, TDCPP, and TPP with a concentration of $10 \mathrm{wt} \%$ (Table 2). TBP, TCEP, TCPP (mixture of isomers), TDCPP, and TCP (mixture of isomers) standards come from Sigma-Aldrich (St. Louis, MO, USA). TEP was supplied by Merck (Darmstadt, Germany) and TPP by ICL-products (Amsterdam, the Netherlands).

Four commercial polyurethane foams were also studied. No information was supplied concerning the composition or the classification of fire resistance of these materials. Model materials as well as commercial samples were stored in aluminum foil at room temperature until analysis (ISO 16000-11 2006). 
Table 1 Physicochemical properties of the studied phosphorus flame retardants

\begin{tabular}{|c|c|c|c|c|c|c|}
\hline & & Formula & CAS & $\begin{array}{l}\text { Boiling point } \\
\left({ }^{\circ} \mathrm{C}\right)^{\mathrm{a}}\end{array}$ & $\begin{array}{l}\text { Vapor pressure } \\
(\mathrm{mmHg})^{\mathrm{a}, \mathrm{b}}\end{array}$ & $\log K_{o a}^{a, b, c}$ \\
\hline TEP & Triethyl phosphate & $\left(\mathrm{C}_{2} \mathrm{H}_{5} \mathrm{O}\right)_{3} \mathrm{PO}$ & $78-40-0$ & 233 & $1.65 \mathrm{E}-01$ & 6.632 \\
\hline TBP & Tributyl phosphate & $\left(\mathrm{CH}_{3}\left(\mathrm{CH}_{2}\right)_{3} \mathrm{O}\right)_{3} \mathrm{PO}$ & $126-73-8$ & 327 & $3.49 \mathrm{E}-03$ & 8.239 \\
\hline TCEP & Tris(2-chloroethyl)-phosphate & $\left(\mathrm{ClCH}_{2} \mathrm{CH}_{2} \mathrm{O}\right)_{3} \mathrm{P}(\mathrm{O})$ & $115-96-8$ & 352 & $3.91 \mathrm{E}-04$ & 5.311 \\
\hline ТCPP & Tris-(monochloropropyl)-phosphate & $\mathrm{C}_{9} \mathrm{H}_{18} \mathrm{Cl}_{3} \mathrm{O}_{4} \mathrm{P}$ & $13,674-84-5$ & 365 & $5.64 \mathrm{E}-05$ & 8.203 \\
\hline TDCPP & Tris-(dichloropropyl)-phosphate & $\mathrm{C}_{9} \mathrm{H}_{15} \mathrm{Cl}_{6} \mathrm{O}_{4} \mathrm{P}$ & $13,674-87-8$ & 459 & $2.86 \mathrm{E}-07$ & 10.622 \\
\hline TPP & Triphenyl phosphate & $\left(\mathrm{C}_{6} \mathrm{H}_{5} \mathrm{O}\right)_{3} \mathrm{PO}$ & $115-86-6$ & 441 & $4.72 \mathrm{E}-07$ & 8.459 \\
\hline TCP & Tricresyl phosphate & $\left(\mathrm{CH}_{3} \mathrm{C}_{6} \mathrm{H}_{4} \mathrm{O}\right)_{3} \mathrm{PO}$ & $1330-78-5$ & 476 & $1.21 \mathrm{E}-02$ & 9.591 \\
\hline
\end{tabular}

${ }^{a}$ Estimated values (US Environmental Protection Agency's Office of Pollution Prevention and Toxics and Syracuse Research Corporation 2012)

${ }^{\mathrm{b}}$ At $25^{\circ} \mathrm{C}$

${ }^{\mathrm{c}} \mathrm{K}_{\mathrm{oa}}$ : octanol-air partition coefficient, corresponding to mass of compound dissolved in octanol per volume of octanol normalized by the mass concentration of gaseous compound (Weschler and Nazaroff 2010)

Headspace—solid phase micro-extraction (HS-SPME)

Studied foams were cut and cubes about $1 \mathrm{~cm}^{3}$ were randomly sampled at different sample locations to be representative of the entire foam panel. Then, cubes were precisely weighed and placed in 10-ml headspace glass vials (Macherey Nagel, Düren, Germany) which were closed with crimp seals with PTFE/silicone septa. HSSPME was carried out using a CombiPAL autosampler from CTC Analytics (Zwingen, Switzerland). One hundred micrometer polydimethylsiloxane (PDMS) SPME fibers were used (Supelco, Bellefonte, PA, USA). The HS-SPME method was optimized. First, the incubation temperature was selected. In order to obtain the highest sensitivity, equilibrium between the material and the gas phase in headspace vial is required. So, different incubation times $(3,5,7,10$, and $12 \mathrm{~min})$ were tested before SPME extraction for the PU $+5 \%$ FRs foam. Then, the SPME fiber is introduced in the vial and equilibrium between the gas phase and the fiber coating was determined by performing extractions from 1 to $25 \mathrm{~min}$.

GC-MS analysis

A Varian CP-3800 gas chromatograph was used coupled with a 1200Q quadrupole mass spectrometer (Varian, Les Ulis, France). The PTV 1079 injection port was equipped with a $0.75-\mathrm{mm}$ i.d. liner and operated at $250{ }^{\circ} \mathrm{C}$ in splitless mode. The carrier gas was helium with a flow rate of $2 \mathrm{ml} \mathrm{min}^{-1}$. A $5 \%$ phenyl capillary
Table 2 List of home-made model materials

\begin{tabular}{|c|c|c|c|c|c|c|c|c|}
\hline \multirow[t]{2}{*}{ Material } & \multirow{2}{*}{$\begin{array}{l}\text { Density } \\
\left(\mathrm{kg} \mathrm{m}^{-3}\right)\end{array}$} & \multicolumn{7}{|c|}{ Composition in flame retardants ( $\mathrm{mg} \mathrm{g}^{-1}$ of foam) } \\
\hline & & TEP & TBP & TCEP & ТCPP & TDCPP & TPP & TCP \\
\hline Blank PU & 160 & - & - & - & - & - & - & - \\
\hline $\begin{array}{c}\mathrm{PU}+10 \% \\
\mathrm{TCPP}\end{array}$ & 160 & - & - & - & 100 & - & - & - \\
\hline $\begin{array}{c}\mathrm{PU}+10 \% \\
\text { TDCPP }\end{array}$ & 160 & - & - & - & - & 100 & - & - \\
\hline $\mathrm{PU}+10 \% \mathrm{TPP}$ & 160 & - & - & - & - & - & 100 & - \\
\hline $\mathrm{PU}+5 \% \mathrm{FRs}$ & 200 & 50 & 50 & 50 & 50 & 50 & 50 & 50 \\
\hline $\begin{array}{l}\mathrm{PU}+7.6 \% \\
\text { FRs }\end{array}$ & 200 & 76 & 76 & 76 & 76 & 76 & 76 & 76 \\
\hline
\end{tabular}


column of $60 \mathrm{~m}, 0.25 \mathrm{~mm}$ i.d. and a film thickness of $1 \mu \mathrm{m}$ was used. The oven temperature was maintained 2 min at $60^{\circ} \mathrm{C}$, then ramped at $30^{\circ} \mathrm{C} \cdot \mathrm{min}^{-1}$ to $200{ }^{\circ} \mathrm{C}$, held for $2 \mathrm{~min}$, then ramped at $15^{\circ} \mathrm{C} \min ^{-1}$ to $310{ }^{\circ} \mathrm{C}$, held for $22 \mathrm{~min}$. The transfer line to the MS was maintained at $250{ }^{\circ} \mathrm{C}$ and the ion source at $250{ }^{\circ} \mathrm{C}$. Acquisition was performed in electron impact (EI) mode at $70 \mathrm{eV}$. The acquisition rate was $0.4 \mathrm{scan} \mathrm{s}^{-1}$. The acquisition mass range was 50-470 amu for TEP and TBP, and single ion monitoring mode (SIM) was used for the others to increase sensitivity. The selected ions are presented in Table 3. The identification was confirmed by retention time compared to commercial standards. For the incubation and extraction determination, the amount of PFRs sorbed on the fiber was determined by an external calibration of standard mixtures in methanol (Ludovic Tuduri et al. 2000).

Quantitative analysis: standard addition method

To determine the PFRs volatile fraction of the foams, the calibration method should be as representative as possible of the links between the PFRs and the material matrix. In this aim, standard addition seems suitable. Several $1 \mathrm{~cm}^{3}$ pieces of a same foam sample were placed and precisely weighted in headspace vials and spiked by introducing in the foam the needle of a syringe containing known amounts of pure compounds before sealing the vials. Each spiked sample piece was then analyzed in the same conditions than the unspiked ones. To assess matrix effects due to the foam, a calibration without foam sample was also performed: increasing amounts of a TCPP standard solution were deposited directly into empty vials and analyzed as the foam samples. In the same way, a calibration curve was determined for each studied foam sample in order to take into account the possible response variation due to matrix effects.

Table 3 Ions for SIM acquisition

\begin{tabular}{llr}
\hline & & $\mathrm{m} / \mathrm{z}$ \\
\hline TCEP & Tris(2-chloroethyl)-phosphate & 63 \\
TCPP & Tris-(monochloropropyl)-phosphate & 99 \\
TDCPP & Tris-(dichloropropyl)-phosphate & 99 \\
TPP & Triphenyl phosphate & 326 \\
TCP & Tricresyl phosphate & 368 \\
\hline
\end{tabular}

\section{Results and discussions}

Method development

\section{SPME fiber selection}

Studies showed that polydimethylsiloxane (PDMS) fiber is suitable for organophosphorus triesters extraction (Ellis et al. 2007; Isetun and Nilsson 2005; Isetun et al., 2004a, b). Polydimethylsiloxane/divinylbenzene (PDMS/DVB) and polydimethylsiloxane/ divinylbenzene/carboxen (PDMS/DVB/CAR) fibers can lead to a better sensitivity that PDMS fiber (Shah et al. 2006; Van der Veen and de Boer 2012). But competitive adsorption can occur while this is less the case for absorption-type fiber such as PDMS (L. Tuduri et al. 2001). In addition, preliminary tests showed that many compounds emitted by foam samples, such as alcohols or alkanes, are detected with PDMS/DVB fiber, while PDMS one appears more selective because only a limited number of compounds including phosphorus flame retardants were detected. It therefore allows avoiding co-elution with the compounds of interest. Due to a larger phase volume, $100 \mu \mathrm{m}$ PDMS fiber lead to a better sensitivity than other thinner PDMS coatings (30 and $7 \mu \mathrm{m}$ ) (Isetun et al., 2004b). The $100 \mu \mathrm{m}$ PDMS fiber seems to be the best compromise for phosphorus flame retardant analysis and was chosen for this study.

\section{Incubation temperature selection}

Twenty-three degree Celsius is representative of ambient conditions of occupied building and is also recommended in the ISO 16000-9 standard test for the determination of VOCs emitted by building and decoration materials (ISO 16000-9 2006). Studies at $23{ }^{\circ} \mathrm{C}$ are needed to assess the releasable part of phosphorus flame retardants under normal use. Higher temperatures are also usually applied to simulate extreme conditions of use such as exposure to sunlight through a window or in passenger compartment of vehicle: $60^{\circ} \mathrm{C}$ is the temperature used to simulate exposure through a window glazing in the ISO 4892-2 standard (ISO 4892-2 2013). Incubation temperatures of 23 and $60{ }^{\circ} \mathrm{C}$ were therefore envisaged for this study.

Preliminary tests were carried out at $23{ }^{\circ} \mathrm{C}$ (SPME extraction time was arbitrarily fixed at $15 \mathrm{~min}$ for all trials). They showed bad reproducibility with relative standard deviation (RSD) up to $40 \%$. As stated in 
Fig. 1 Influence of the incubation temperature on PFRs emission. SPME sampling of PFRs in PU $+5 \%$ FRs (a) and PU $+10 \%$ TCPP (b) samples, 3 min incubation for each temperature, SPME: $15 \mathrm{~min}$

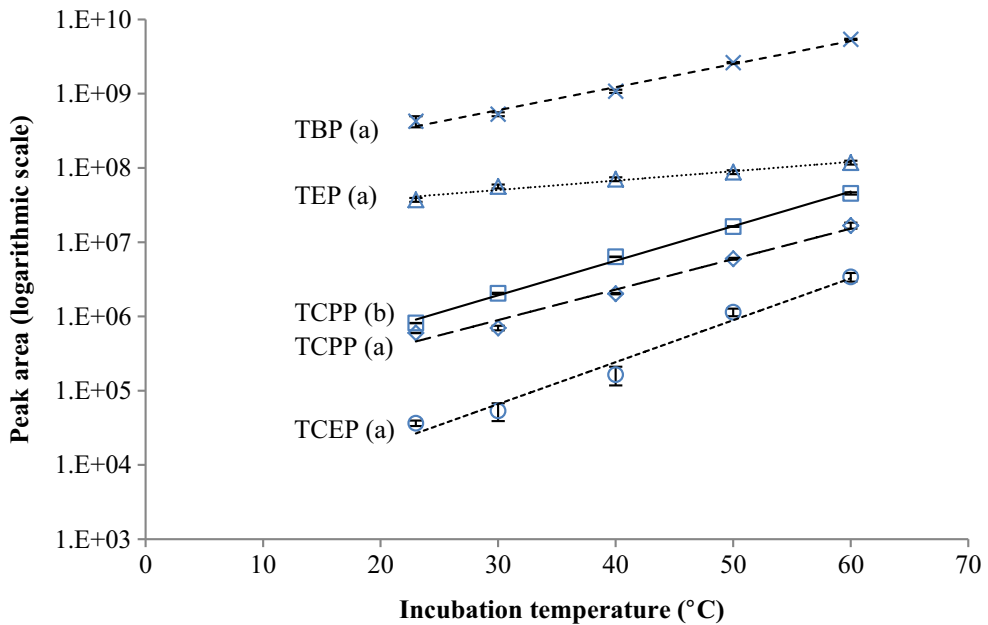

$\mathrm{PU}+10 \% \mathrm{TCPP}$ ) meet the same temperature influence with very similar slope values (13\% difference) (Table 4). The temperature effect might seem to depend on the compound but not on the foam matrix. As first assessment of this assumption, a comparison between measured and extrapolated values at $23{ }^{\circ} \mathrm{C}$ for different commercial foams is presented in section 3.5.3.

\section{Incubation time determination}

At $60{ }^{\circ} \mathrm{C}$, the extracted amounts of PFRs are not significantly different for incubation times between 3 and $12 \mathrm{~min}$ (Fig. 2) indicating that solid (foam)/gas equilibrium is rapidly reached for these compounds. Since this is sufficient to reach equilibrium, an incubation time of 3 min was selected so that the method would be fast to implement.

Table 4 Correlation coefficients and slopes of $\log$ (peak area) $=\mathrm{f}$ (incubation temperature) curves for SPME sampling of PFRs in $\mathrm{PU}+5 \% \mathrm{FRs}$ and PU $+10 \% \mathrm{TCPP}$

\begin{tabular}{llllc}
\hline Compound & Sample & $\mathrm{r}^{2}$ & Slope & RSD $(\%)^{\mathrm{a}}$ \\
\hline TEP & PU + 5 \% FRs & 0.9903 & 0.0142 & 6.1 \\
TBP & PU + 5 \% FRs & 0.9871 & 0.0322 & 6.4 \\
TCEP & PU + 5 \% FRs & 0.9912 & 0.0569 & 13.4 \\
TCPP & PU + 5 \% FRs & 0.9848 & 0.0412 & 4.5 \\
TCPP & PU + 10\% TCPP & 0.9967 & 0.0466 & 4.5 \\
\hline
\end{tabular}

${ }^{\text {a }}$ Average of the RSD values obtained for the 5 studied temperatures, $n=3$ for each temperature 

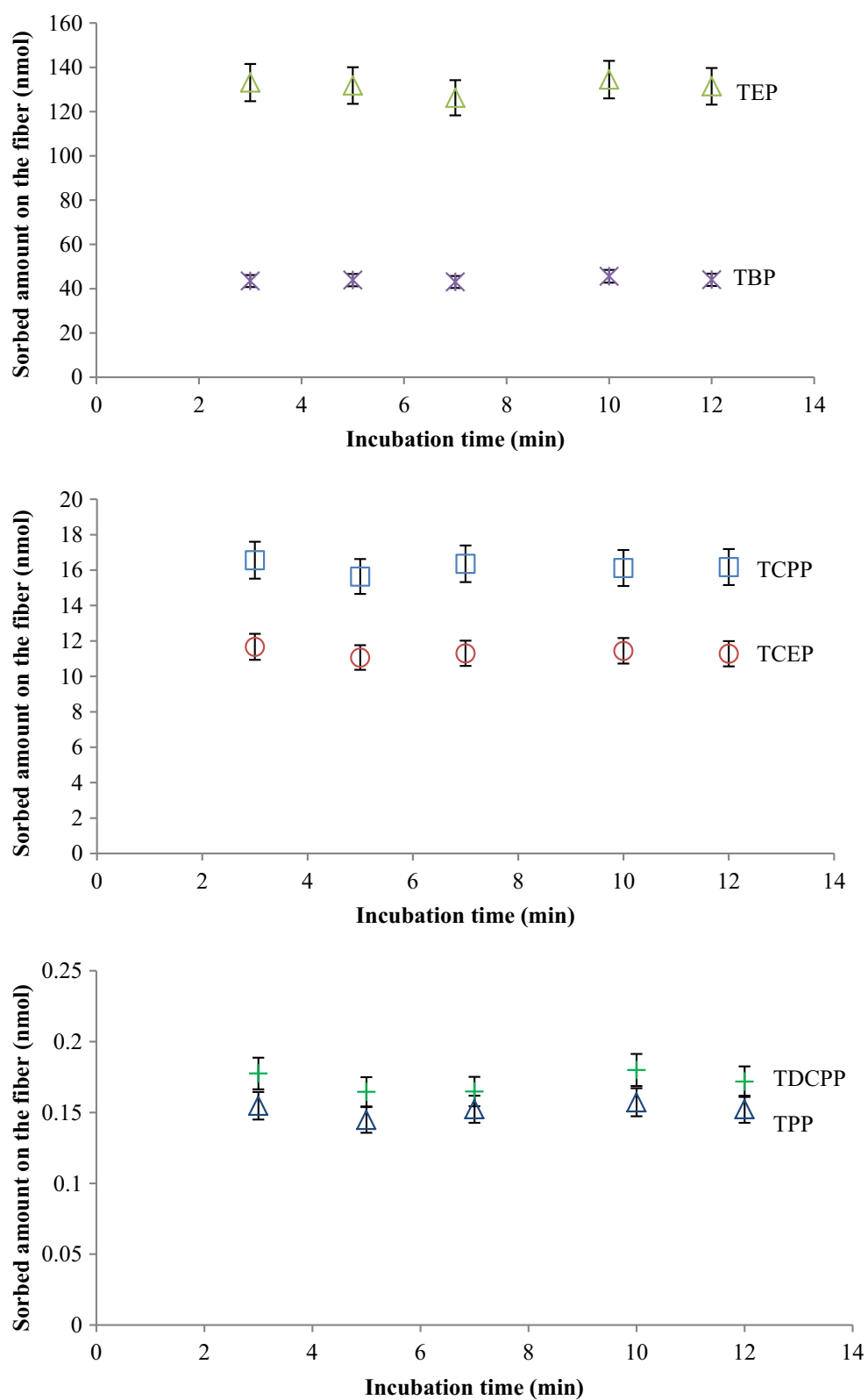

Fig. 2 Sorbed amount of PFRs on PDMS fiber depending on the incubation time at $60{ }^{\circ} \mathrm{C}, \mathrm{PU}+5 \%$ FRs sample, 15 min extraction

\section{Extraction time determination}

In order to obtain the highest sensitivity, equilibrium of PFRs concentration between the gas phase and the fiber is desired. This equilibrium is quickly reached for the most volatile PFRs (TEP and TBP, Fig. 3). The extraction kinetics are slower for TCEP and TCPP, and equilibrium is not even reached after
$25 \mathrm{~min}$ for the least volatile compounds (TDCPP and TPP) and their sorbed amounts on the fiber are low (Fig. 3). TCP is only detected after $10 \mathrm{~min}$ of extraction but is not quantifiable. This result suggests that these low volatile flame retardants (b.p. $>400{ }^{\circ} \mathrm{C}$ ) might present a lower risk in terms of human exposure compared to the more volatile ones. Consequently, TCP, TPP, and TDCPP have not been 

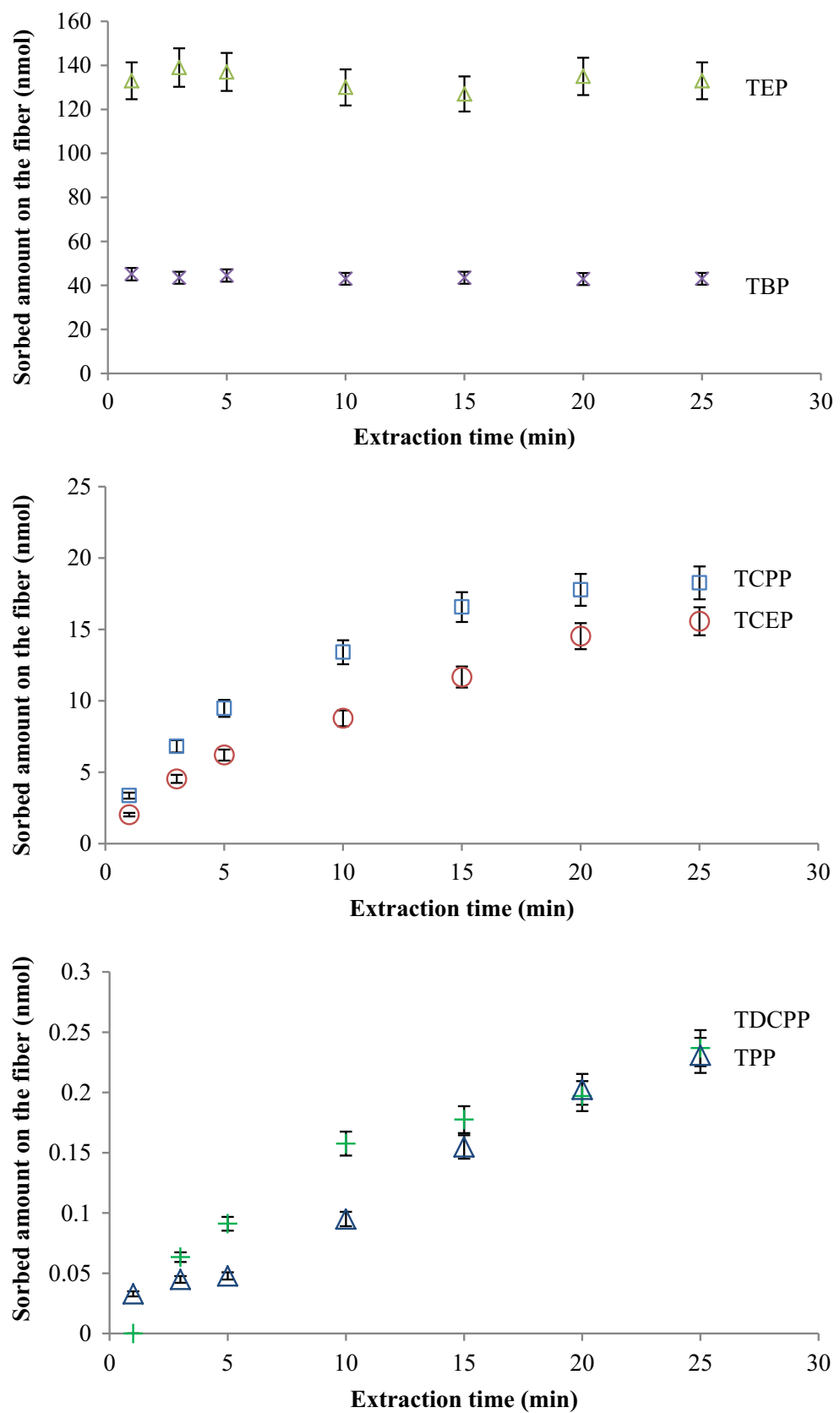

Fig. 3 Kinetic of SPME extraction of phosphorus flame retardants in model material (PU + $5 \%$ FRs) with PDMS fiber, after an incubation at $60{ }^{\circ} \mathrm{C}$ for $3 \mathrm{~min}$

quantified in the next stages of this study. Although the equilibrium between the gas phase and the fiber is not reached for all detected PFRs, an extraction time of $15 \mathrm{~min}$ was selected as it represents a good compromise between sensitivity and analysis time.
Analytical performances

To summarize, the developed HS-SPME method consists to incubate $3 \mathrm{~min}$ at $60{ }^{\circ} \mathrm{C} 1 \mathrm{~cm}^{3}$ foam samples in sealed vials. Then a 15 min extraction is performed with a $100 \mu \mathrm{m}$ PDMS SPME fiber 
Table 5 Limits of detection (LOD) obtained for HS-SPME-GCMS (SIM mode) analyses at $60^{\circ} \mathrm{C}$

\begin{tabular}{ll}
\hline & $\begin{array}{l}\text { LOD } \\
\left(\mu \mathrm{g} \mathrm{g}^{-1} \text { of foam) }\right.\end{array}$ \\
\hline Triethyl phosphate (TEP) & $0.72 \pm 0.04$ \\
Tributyl phosphate (TBP) & $1.06 \pm 0.07$ \\
Tris(2-chloroethyl)-phosphate (TCEP) & $0.33 \pm 0.02$ \\
Tris-(monochloropropyl)-phosphate (TCPP) & $1.29 \pm 0.08$ \\
\hline
\end{tabular}

which is analyzed by GC-MS. The performances of this HS-SPME method were determined hereafter.

\section{Analytical system blanks}

To check losses, contaminations and memory effects due to the analytical system, analytical blanks (analysis of empty headspace vials) were performed at the beginning and during each sequence of analysis. Results showed that sampling vials, SPME fiber, analytical system and laboratory air do not bring any organophosphorus flame retardants or any other compound which can interfere on analysis. Furthermore, blanks during the sequences proved that there was no memory effect between two consecutive samples. The polyurethane foam sample without flame retardant (Blank PU) was used as a negative control and confirmed the absence of contamination during samples preparation.

\section{Repeatability}

Five pieces of the same unspiked material sample were analyzed at $60{ }^{\circ} \mathrm{C}$, in the same conditions: 3 min incubation at $60{ }^{\circ} \mathrm{C}, 15 \mathrm{~min}$ SPME extraction at $60^{\circ} \mathrm{C}$ with the $100 \mu \mathrm{m}$ PDMS fiber (section 2.2) and GC-MS analysis (section 2.3). Despite random sampling, a good analytical repeatability of the implemented method was obtained with a relative standard deviation (RSD) of $6.3 \%$. This result showed that $1 \mathrm{~cm}^{3}$ cubes are representative of the entire foam panel, and that this latter is homogeneous.

\section{Limit of detection}

The limits of detection of the method for the various compounds tested are shown in Table 5. These values correspond to the amount of each compound in foam for a signal to noise ratio of 3 .

\section{Calibration}

Standard addition on a model material (PU $+10 \%$ TCPP) was compared to a calibration without material (empty vial). The two calibration curves provide a good linearity with correlation coefficients up to 0.99 . The slope of the calibration curve is higher without sample than when foam is analyzed (Fig. 4). This result shows the "matrix effect" of the polyurethane foam on the chromatographic response. That means that standard addition is necessary and that external calibration cannot be applied for a reliable quantification of the volatile fraction of PFRs. This matrix effect may be different
Fig. 4 Calibration curves of TCPP in model material $(\mathrm{PU}+10 \% \mathrm{TCPP})(\mathrm{O})$ and without material $(\times)$, analysis at $60{ }^{\circ} \mathrm{C}$

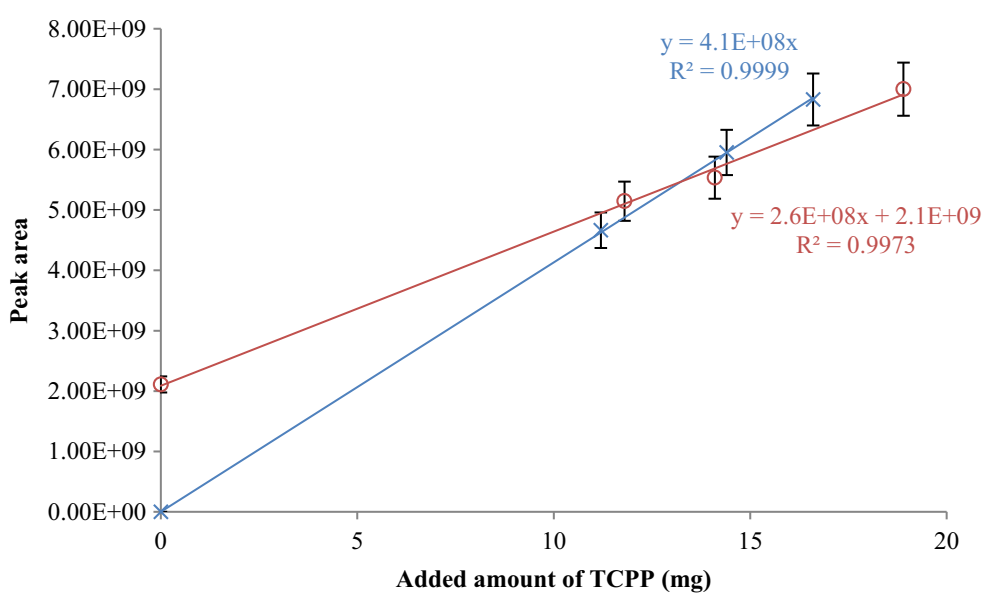


Table 6 Volatile fraction of flame retardants in model materials (mg g ${ }^{-1}$ of foam) at $60{ }^{\circ} \mathrm{C}$

Data inside brackets show the percentage of the initial amount incorporated in the foam

\begin{tabular}{lllll}
\hline Sample & TEP & TBP & TCEP & TCPP \\
\hline PU + 10\% TCPP & - & - & - & $44 \pm 3$ \\
PU + 5 \% FRs & $49 \pm 3$ & $24 \pm 2$ & $13.9 \pm 0.9$ & $(44 \pm 3 \%)$ \\
& $(98 \pm 6 \%)$ & $(48 \pm 4 \%)$ & $(28 \pm 2 \%)$ & $(33 \pm 2 \%)$ \\
PU + 7.6 \% FRs & $71 \pm 5$ & $50 \pm 3$ & $23 \pm 1.1$ & $31 \pm 2$ \\
& $(93 \pm 7 \%)$ & $(66 \pm 4 \%)$ & $(30 \pm 1 \%)$ & $(41 \pm 3 \%)$ \\
\hline
\end{tabular}

depending on the compound and the material, so a calibration by standard addition was carried out for each compound and each material type.

Calibration of PU $+10 \%$ TCPP model material by standard addition method at $60^{\circ} \mathrm{C}$ was repeated thrice. Results showed the good repeatability of the calibration with a variation of $3.9 \%$ (RSD for TCPP) between the three calibration slopes.

Determination of the volatile fraction of PFRs in model materials

Calibration by standard addition was used to determine the volatile fraction of flame retardants in model materials (Table 6). This fraction directly depends on compound volatility (Table 1) and can be very high relative to the total amount incorporated in the polyurethane foam. This represents almost all of incorporated TEP $(98 \%)$ at $60{ }^{\circ} \mathrm{C}$ (Tables 2 and 6). For less volatile compounds such as TDCPP, TPP, or TCP, this part is very low even at $60^{\circ} \mathrm{C}$ and is not quantifiable. So the used of these compounds in polyurethane foams of upholstered furniture will lead to lower exposure in indoor environment. In recent years, there is a tendency to use less volatile PFRs: resorcinolbis(diphenylphosphate) (b.p. $=587^{\circ} \mathrm{C}$ ) is often used as a substitute for TCEP and TCPP. Because of its lower volatility, it is less likely to be release into the environment (Van der Veen and de Boer 2012).

Quantification of TCPP emitted by various model materials (PU $+10 \%$ TCPP, PU $+7.6 \%$ FRs, and PU + $5 \%$ FRs) allows observing a relationship between the volatile fraction and the amount initially incorporated into the material (Fig. 5). These first results show a trend that should be further confirmed with other model materials at different incorporation rates. The volatile fraction of TCPP represents 34,41 , and $44 \%$ of the amount initially incorporated for PU $+5 \%$ FRs, PU $+7.6 \%$ FRs, and PU $+10 \%$ TCPP, respectively. This part therefore not only depends on compound volatility but also on the initial incorporation rate in the foam: the higher the initial amount added is, the lower the compound is retained by the PU foam. This could be due to
Fig. 5 Relationship between the volatile fraction of TCPP and its initial amount in polyurethane foam (PU $+10 \% \mathrm{TCPP})$, at $60^{\circ} \mathrm{C}$

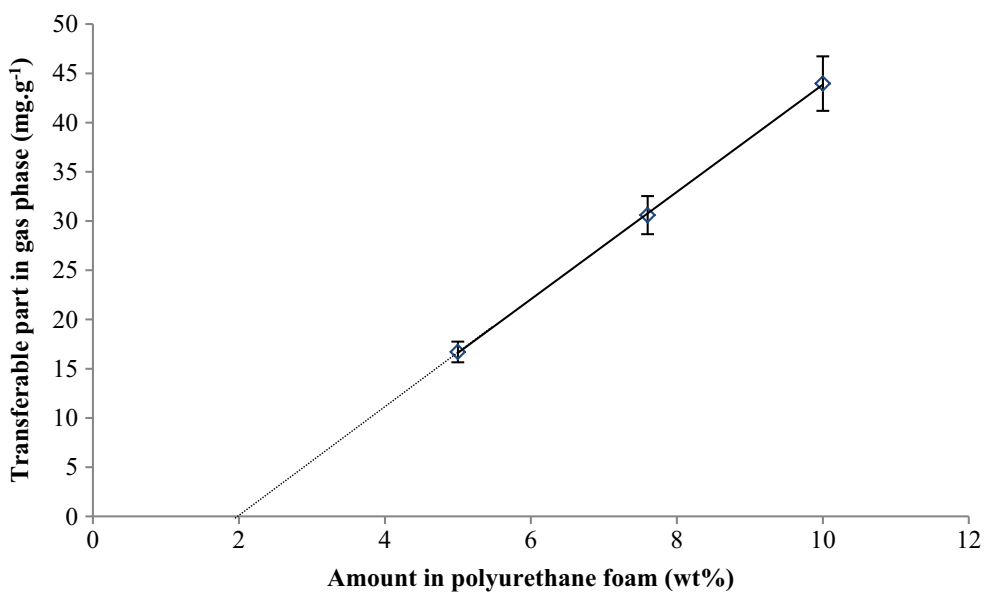


the progressive saturation of the foam, but this assumption was not yet verified. This trend also shows that below a given incorporation rate (about $2 \mathrm{wt} \%$ ), the volatile fraction becomes very low $(<\mathrm{LOD})$ and is no longer detected meaning that rate of $2 \mathrm{wt} \%$ would have lower health impacts, but to be efficient, the incorporation rates are generally up to $6.9 \%$ (ANSES 2013; Stapleton et al. 2009).

Application to commercial samples

\section{Qualitative analysis}

All studied commercial polyurethane foams contain phosphorus flame retardants and all release TCPP (Table 7). Predominance of TCPP in the studied samples is consistent with bibliographic data on the use of flame retardants in upholstered furniture. TBP was also detected for three of the four samples but volatile fractions are below the LOD. Given these results, quantitative analysis on commercial samples were limited to TCPP.

\section{Quantitative analysis}

A comparison of calibration curves for polyurethane foams samples shows very different matrix effects. Indeed, a significant difference of the slopes can be noted (Table 8). The higher the slope, the lower the material retains the flame retardants. PU 1 thus retains highly TCPP, and the volatile fraction (up to 75 times lower than the others) probably represents a small rate of the total amount of the sample. On the contrary, PU 2, PU 3, and PU 4 show very high volatile fractions of TCPP (up to $136 \mathrm{mg} \mathrm{g}^{-1}$ for PU 3). According to their calibration slopes, these foams would have a lower capacity to retain TCPP than PU 1. This behavior seems to be related to the physical properties of the foams: increasing densities correspond to lower the volatile fraction of

Table 7 Qualitative analysis of the volatile fraction of phosphorus flame retardants in commercial foams, at $60{ }^{\circ} \mathrm{C}$, + detected, undetected

\begin{tabular}{llllllll}
\hline Sample & TEP & TBP & TCEP & TCPP & TDCPP & TPP & TCP \\
\hline PU 1 & - & + & - & + & - & - & - \\
PU 2 & - & + & - & + & - & - & - \\
PU 3 & - & - & - & + & - & - & - \\
PU 4 & - & + & - & + & - & - & - \\
\hline
\end{tabular}

Table 8 Slopes of calibration curves and volatile fraction of TCPP in commercial foams at $60{ }^{\circ} \mathrm{C}$

\begin{tabular}{llll}
\hline Foam & $\begin{array}{l}\text { Foam } \\
\text { density } \\
\left(\mathrm{kg} \mathrm{m}^{-3}\right)\end{array}$ & $\begin{array}{l}\text { Slope of } \\
\text { calibration } \\
\text { curve }\end{array}$ & $\begin{array}{l}\text { Volatile fraction at } 60{ }^{\circ} \mathrm{C} \\
\left(\mathrm{mg} \mathrm{g}^{-1} \text { of foam }\right)\end{array}$ \\
\hline PU 1 & 62 & $2.7 \mathrm{E}+7$ & $1.8 \pm 0.1$ \\
PU 2 & 45 & $9.1 \mathrm{E}+7$ & $77 \pm 5$ \\
PU 3 & 37 & $1.1 \mathrm{E}+8$ & $136 \pm 9$ \\
PU 4 & 27 & $1.5 \mathrm{E}+8$ & $91 \pm 6$ \\
\hline
\end{tabular}

TCPP (Table 8). Cell size and thickness of cell walls of PU foams, as well as the fraction of closed and open cells would also play a role in PFR retention. Moreover, the initial amount of PFRs and the processing parameters of incorporation may also affect the transfer in gas phase. But the lack of information on these commercial foams does not allow deepening the interpretation of these results.

Extrapolation of the results obtained at $60^{\circ} \mathrm{C}$ to $23^{\circ} \mathrm{C}$

A linear relationship between the logarithm of the volatile fraction in gas phase and the incubation temperature was obtained (Incubation temperature selection section). In order to assess the ability to determine the volatile fraction of FPRs at $23{ }^{\circ} \mathrm{C}$ by extrapolating the results obtained at $60{ }^{\circ} \mathrm{C}$, comparison between experimental and extrapolated results was performed.

Firstly, the volatile fraction of TCPP in the commercial foams at $23{ }^{\circ} \mathrm{C}$ was determined experimentally by standard addition. To overcome analyte losses and poor reproducibility due to wall deposition at this temperature, all the necessary analytical precautions were taken (Incubation temperature selection section). Extrapolated

Table 9 Comparison of the volatile fraction ( $\mathrm{mg} \mathrm{g}^{-1}$ of foam) obtained experimentally and with results from $60{ }^{\circ} \mathrm{C}$

\begin{tabular}{llcl}
\hline Sample & $\begin{array}{l}\text { Density } \\
\left(\mathrm{kg} \mathrm{m}^{-3}\right)\end{array}$ & \multicolumn{2}{l}{ Volatile fraction $\left(\mathrm{mg} \mathrm{g}^{-1}\right)$ at $23{ }^{\circ} \mathrm{C}$} \\
\cline { 3 - 4 } & & $\begin{array}{l}\text { Standard addition } \\
\text { method at } 23{ }^{\circ} \mathrm{C}\end{array}$ & $\begin{array}{l}\text { Extrapolation from } \\
60{ }^{\circ} \mathrm{C} \text { results }\end{array}$ \\
\hline PU 1 & 62 & $<\operatorname{LOD}(0.0013)$ & $0.0007 \pm 0.0001$ \\
PU 2 & 45 & $0.020 \pm 0.003$ & $0.028 \pm 0.004$ \\
PU 3 & 37 & $0.040 \pm 0.006$ & $0.050 \pm 0.006$ \\
PU 4 & 27 & $0.030 \pm 0.005$ & $0.033 \pm 0.004$ \\
\hline
\end{tabular}


values from results obtained at $60{ }^{\circ} \mathrm{C}$ were determined by applying the average slope of PU $+10 \%$ TCPP and $\mathrm{PU}+5 \%$ FRs curves (Fig. 1). Obtained results are summarized in Table 9.

For PU 1 sample, TCPP is not detected at $23{ }^{\circ} \mathrm{C}$ and the volatile fraction determined by extrapolation is also consistent with this result $(<\mathrm{LOD})$. For the other samples, the volatile fraction calculated by extrapolation is consistently higher than that determined experimentally. Losses due to wall deposition at $23{ }^{\circ} \mathrm{C}$ could explain an underestimation with the standard addition methods despite analytical precautions. Results are still consistent between the two methods assuming that results for ambient temperatures might be obtained by extrapolation from higher temperatures. This presents certain advantages: only analyses at $60{ }^{\circ} \mathrm{C}$ are required. At this temperature, there is no deposit of the phosphorus flame retardants on the sampler walls. The methodology is thus quite easy to implement and can be automated thanks to the use of an autosampler. Furthermore, extrapolation method allows greater sensitivity: if the compound is quantifiable at $60{ }^{\circ} \mathrm{C}$, an estimation is possible for $23{ }^{\circ} \mathrm{C}$ at lower concentrations than the experimental LOD as shown in the example of PU 1 (Table 9).

\section{Conclusions}

The aim of the present work was to develop an analytical method of the volatile fraction of phosphorus flame retardants released by materials of upholstered furniture by headspace coupled to solid-phase micro-extraction. The developed method allows a rapid qualitative screening of phosphorus flame retardants that can be released by upholstery materials and transferred in air. The quantitative analysis method requires a calibration by standard addition for each studied material and each compound but provides important information dealing with the ability of material to retain or release PFRs.

The volatile fraction of TCPP in commercial and home-made additive polyurethane foams was shown to be an important part of the initially incorporated amount, especially under extreme temperatures of use such as $60{ }^{\circ} \mathrm{C}$. It has to be noticed that the density of foams and probably other structure parameters influence significantly the transfer to gas phase.
Even though this study does not consider the multilayer composition of the furniture and its possible barrier effect to FRs releases, it highlights that air might be a major vector of the contamination of indoor environments. Then, according to FRs physicochemical properties, a partitioning between air and solid surfaces will occur, leading to different pathways of exposure such as inhalation or skin contact with surfaces. This latter is supported by the deposit of the compounds on the sampler walls observed during the development of the analytical method, especially at $23{ }^{\circ} \mathrm{C}$.

Phosphorus flame retardant analysis method by HSSPME was developed and tested on PU cushioning foams but can also be applied to any other type of materials.

Acknowledgments Authors acknowledge Angelique De Nieva for the synthesis of the model materials.

\section{References}

Ali, N., Dirtu, A. C., Van den Eede, N., Goosey, E., Harrad, S., Neels, H., et al. (2012). Occurrence of alternative flame retardants in indoor dust from New Zealand: indoor sources and human exposure assessment. Chemosphere, 88(11), 1276-1282. doi:10.1016/j.chemosphere.2012.03.100.

Altwaiq, A. M., Wolf, M., \& van Eldik, R. (2003). Extraction of brominated flame retardants from polymeric waste material using different solvents and supercritical carbon dioxide. Analytica Chimica Acta, 491(1), 111-123. doi:10.1016 /S0003-2670(03)00785-2.

ANSES (2013). Risques liés à l'exposition aux retardateurs de flamme des meubles rembourrés. https://www.anses. $\mathrm{fr} / \mathrm{fr} / \mathrm{system} /$ files/SUBCHIM2011sa0132Ra-01.pdf. Accessed 5 Aug 2015.

ANSES (2015). Evaluation des risques liés à l'exposition aux retardateurs de flamme dans les meubles rembourrés : Partie 2-Evaluation des effets sur la santé et sur l'environnement, et estimation qualitative du rapport bénéfices/risques. https://www.anses.fr/fr/system/files/CONSO2011sa0132Ra02.pdf. Accessed 20 Oct 2015.

Aragón, M., Borrull, F., \& Marcé, R. M. (2013). Thermal desorption-gas chromatography-mass spectrometry method to determine phthalate and organophosphate esters from air samples. Journal of Chromatography. A, 1303, 76-82. doi:10.1016/j.chroma.2013.06.025.

Beth-Hubner, M., \& Devilliers, B. (1999). Toxicological evaluation and classification of the genotoxic, carcinotoxic, reprotoxic and sensitising potential of the tris(2chloroethyl)phosphate. International Archives of Occupational and Environmental Health, 72(11), 17-23.

Björklund, J., Isetun, S., \& Nilsson, U. (2004). Selective determination of organophosphate flame retardants and plasticizers in indoor air by gas chromatography, positive-ion chemical ionization and collision-induced dissociation mass 
spectrometry. Rapid communications in mass spectrometry: RCM, 18(24), 3079-3083. doi:10.1002/rcm.1721.

Carlsson, H., Nilsson, U., Becker, G., \& Östman, C. (1997). Organophosphate Ester flame retardants and plasticizers in the indoor environment: analytical methodology and occurrence. Environmental Science \& Technology, 31(10), 29312936. doi:10.1021/es970123s.

Chivas, C., Guillaume, E., \& Sainrat, A. (2007). Etude sur les effets de l'ignifugation de certains meubles rembourrés dans le cadre d'un projet de réglementation relative à la sécurité incendie : Partie 1-Etat de 1'art. Document LNE, Projet R\&D 27EAF6707. https://www.lne.fr/fr/actualites/pdf/meublesrembourres-toxicite-ignifugeants-Etat-de-1-art.pdf. Accessed 8 Aug 2015.

Covaci, A., Gerecke, A. C., Law, R. J., Voorspoels, S., Kohler, M., Heeb, N. V., et al. (2006). Hexabromocyclododecanes (HBCDs) in the environment and humans: a review. Environmental Science and Technology, 40(12), 36793688. doi:10.1021/es0602492.

Dishaw, L. V., Powers, C. M., Ryde, I. T., Roberts, S. C., Seidler, F. J., Slotkin, T. A., \& Stapleton, H. M. (2011). Is the PentaBDE replacement, tris (1,3-dichloro-2-propyl) phosphate (TDCPP), a developmental neurotoxicant? Studies in PC12 cells. Toxicology and Applied Pharmacology, 256(3), 281289. doi:10.1016/j.taap.2011.01.005.

Ellis, J., Shah, M., Kubachka, K. M., \& Caruso, J. A. (2007). Determination of organophosphorus fire retardants and plasticizers in wastewater samples using MAE-SPME with GCICPMS and GC-TOFMS detection. Journal of Environmental Monitoring, 9(12), 1329-1336. doi:10.1039/b710667j.

European Chemicals Agency (2016). Community Rolling Action Plan (CoRAP) - Substance evaluation. https://echa.europa. eu/documents/10162/13628/corap_list_2016-2018_en.pdf. Accessed 12 Apr 2016.

European flame retardants association (2015). Utilisation de retardateurs de flamme. http://www.cefic-efra.com/index. $\mathrm{php} / \mathrm{fr} /$ furniture-a-textile-fr/use-of-flame-retardants-fr-fr. Accessed 8 Aug 2015.

Félix, J. S., Domeño, C., \& Nerín, C. (2013). Characterization of wood plastic composites made from landfill-derived plastic and sawdust: volatile compounds and olfactometric analysis. Waste Management, 33(3), 645-655. doi:10.1016/j. wasman.2012.11.005.

French Minister of Housing and Sustainable Habitat (2015). Coup d'envoi de la campagne nationale de prévention contre les incendies domestiques. Coup d?envoi de la campagne nationale de pr?vention contre les incendies domestiques. Accessed 5 Aug 2015.

Gröning, M., \& Hakkarainen, M. (2001). Headspace solid-phase microextraction - a tool for new insights into the long-term thermo-oxidation mechanism of polyamide 6.6. Journal of Chromatography A, 932(1-2), 1-11. doi:10.1016/S00219673(01)01230-4.

Hartmann, P. C., Bürgi, D., \& Giger, W. (2004). Organophosphate flame retardants and plasticizers in indoor air. Chemosphere, 57(8), 781-787. doi:10.1016/j.chemosphere.2004.08.051.

Isetun, S., \& Nilsson, U. (2005). Dynamic field sampling of airborne organophosphate triesters using solid-phase microextraction under equilibrium and non-equilibrium conditions. The Analyst, 130(1), 94-98. doi:10.1039/b410597d.
Isetun, S., Nilsson, U., \& Colmsjö, A. (2004a). Evaluation of solid-phase microextraction with PDMS for air sampling of gaseous organophosphate flame-retardants and plasticizers. Analytical and Bioanalytical Chemistry, 380(2), 319-324. doi:10.1007/s00216-004-2760-5.

Isetun, S., Nilsson, U., Colmsjö, A., \& Johansson, R. (2004b). Air sampling of organophosphate triesters using SPME under non-equilibrium conditions. Analytical and Bioanalytical Chemistry, 378(7), 18471853. doi:10.1007/s00216-003-2489-6.

ISO 16000-11 (2006). Indoor air-Part 11: Determination of the emission of volatile organic compounds from building products and furnishing - sampling, storage of samples and preparation of test specimens. International Organization for Standardization.

ISO 16000-25 (2011). Indoor air-Part 25: Determination of the emission of semi-volatile organic compounds by building products-micro-chamber method. International Organization for Standardization.

ISO 16000-9 (2006). Indoor air-Part 9: Determination of the emission of volatile organic compounds from building products and furnishing-emission test chamber method. International Organization for Standardization.

ISO 4892-2 (2013). Plastics - methods of exposure to laboratory light sources-Part 2: Xenon-arc lamps. International Organization for Standardization.

Katsumata, H., Murakami, S., Kato, S., Hoshino, K., \& Ataka, Y. (2008). Measurement of semi-volatile organic compounds emitted from various types of indoor materials by thermal desorption test chamber method. Building and Environment, 43(3), 378-383. doi:10.1016/j.buildenv.2006.03.027.

Kemmlein, S., Hahn, O., \& Jann, O. (2003). Emissions of organophosphate and brominated flame retardants from selected consumer products and building materials. Atmospheric Environment, 37(39-40), 5485-5493. doi:10.1016/j. atmosenv.2003.09.025.

Kotowska, U., Żalikowski, M., \& Isidorov, V. A. (2012). HSSPME/GC-MS analysis of volatile and semi-volatile organic compounds emitted from municipal sewage sludge. Environmental Monitoring and Assessment, 184(5), 28932907. doi:10.1007/s10661-011-2158-8.

Kwon, K.-D., Jo, W.-K., Lim, H.-J., \& Jeong, W.-S. (2007). Characterization of emissions composition for selected household products available in Korea. Journal of Hazardous Materials, 148(1-2), 192-198. doi:10.1016/j. jhazmat.2007.02.025.

Lattuati-Derieux, A., Bonnassies-Termes, S., \& Lavédrine, B. (2006). Characterisation of compounds emitted during natural and artificial ageing of a book. Use of headspace-solidphase microextraction/gas chromatography/mass spectrometry. Journal of Cultural Heritage, 7(2), 123-133. doi:10.1016 j.culher.2006.02.004.

Little, J. C., Weschler, C. J., Nazaroff, W. W., Liu, Z., \& Cohen Hubal, E. A. (2012). Rapid methods to estimate potential exposure to semivolatile organic compounds in the indoor environment. Environmental Science \& Technology, 46(20), 11171-11178. doi:10.1021/es301088a.

Marklund, A., Andersson, B., \& Haglund, P. (2003). Screening of organophosphorus compounds and their distribution in various indoor environments. Chemosphere, 53(9), 1137-1146. doi:10.1016/S0045-6535(03)00666-0. 
Marklund, A., Andersson, B., \& Haglund, P. (2005). Organophosphorus flame retardants and plasticizers in air from various indoor environments. Journal of environmental monitoring: JEM, 7(8), 814-819. doi:10.1039/b505587c.

NF EN 1021-1 (2014). Furniture-assessment of the ignitability of upholstered furniture-Part 1: Ignition source smouldering cigarette. AFNOR.

Official journal of the European Union (2008). Regulation (EC) No 1272/2008 of the European Parliament and of the Council of 16 December 2008 on classification, labelling and packaging of substances and mixtures.

Saboori, A. M., Lang, D. M., \& Newcombe, D. S. (1991). Structural requirements for the inhibition of human monocyte carboxylesterase by organophosphorus compounds. ChemicoBiological Interactions. doi:10.1016/0009-2797(91)90092-L.

Salthammer, T., \& Bahadir, M. (2009). Occurrence, dynamics and reactions of organic pollutants in the indoor environment. CLEAN - Soil, Air, Water, 37(6), 417-435. doi:10.1002 /clen.200900015.

Sato, T., Watanabe, K., Nagase, H., Kito, H., Niikawa, M., \& Yoshioka, Y. (1997). Investigation of the hemolytic effects of various organophosphoric acid triesters (OPEs) and their structurel activity relationship. Toxicological \& Environmental Chemistry, 59, 305-313. doi:10.1080 /02772249709358444.

Shah, M., Meija, J., Cabovska, B., \& Caruso, J. A. (2006). Determination of phosphoric acid triesters in human plasma using solid-phase microextraction and gas chromatography coupled to inductively coupled plasma mass spectrometry. Journal of Chromatography A, 1103(2), 329-336. doi:10.1016/j.chroma.2005.11.042.

Staaf, T., \& Ostman, C. (2005a). Organophosphate triesters in indoor environments. Journal of environmental monitoring: JEM, 7(9), 883-887. doi:10.1039/b506631j.

Staaf, T., \& Ostman, C. (2005b). Indoor air sampling of organophosphate triesters using solid phase extraction (SPE) adsorbents. Journal of environmental monitoring: JEM, 7(4), 344 348. doi:10.1039/b411975d.

Stapleton, H. M., Klosterhaus, S., Eagle, S., Fuh, J., Meeker, J. D., Blum, A., \& Webster, T. F. (2009). Detection of organophosphate flame retardants in furniture foam and U.S. house dust. Environmental Science \& Technology, 43(19), 7490-7495.

Takigami, H., Suzuki, G., Hirai, Y., \& Sakai, S. (2009a). Brominated flame retardants and other polyhalogenated compounds in indoor air and dust from two houses in Japan. Chemosphere, 76(2), 270-277. doi:10.1016/j. chemosphere.2009.03.006.
Takigami, H., Suzuki, G., Hirai, Y., Ishikawa, Y., Sunami, M., \& Sakai, S. (2009b). Flame retardants in indoor dust and air of a hotel in Japan. Environment International, 35(4), 688-693. doi:10.1016/j.envint.2008.12.007.

Tilson, H. A., Veronesi, B., McLamb, R. L., \& Matthews, H. B. (1990). Acute exposure to tris(2-chloroethyl)phosphate produces hippocampal neuronal loss and impairs learning in rats. Toxicology and Applied Pharmacology. doi:10.1016/0041008X(90)90245-P.

Tuduri, L., Desauziers, V., \& Fanlo, J. L. (2000). Determination of absolute amount extracted by solid-phase microextraction: different approaches under examination. Journal of Microcolumn Separations, 12(10), 550-557. doi:10.1002 /1520-667X(2000)12:10<550::AID-MCS4>3.0.CO;2-P.

Tuduri, L., Desauziers, V., \& Fanlo, J. L. (2001). Potential of solidphase microextraction fibers for the analysis of volatile organic compounds in air. Journal of Chromatographic Science, 39(12), 521-529. doi:10.1093/chromsci/39.12.521.

US Environmental Protection Agency's Office of Pollution Prevention and Toxics, \& Syracuse Research Corporation (2012). EPI suiteTM.

Van der Veen, I., \& de Boer, J. (2012). Phosphorus flame retardants: properties, production, environmental occurrence, toxicity and analysis. Chemosphere, 88(10), 1119-1153. doi:10.1016/j.chemosphere.2012.03.067.

Wang, Y., Du, Z., Zhang, Y., Zhou, L., \& Yu, W. (2015). Development of a rapid detection method for eight organophosphate esters in plastic samples from automobile interiors using ultra-performance liquid chromatography tandem mass spectrometry with microwave assisted extraction. Analytical Methods, 7(23), 9861-9866. doi:10.1039/C5AY02077H.

Weschler, C. J., \& Nazaroff, W. W. (2008). Semivolatile organic compounds in indoor environments. Atmospheric Environment, 42(40), 9018-9040. doi:10.1016/j. atmosenv.2008.09.052.

Weschler, C. J., \& Nazaroff, W. W. (2010). SVOC partitioning between the gas phase and settled dust indoors. Atmospheric Environment, 44(30), 3609-3620. doi:10.1016/j. atmosenv.2010.06.029.

World Health Organization (1990). Tricresyl phosphate. Environmental Health Criteria, 110.

World Health Organization (1991). Triphenyl phosphate. Environmental Health Criteria, 111.

World Health Organization (1998). Flame retardants: Tris(chloropropyl) phosphate and Tris(2-chloroethyl) phosphate. Environmental Health Criteria, 209. 